\title{
Preparation of Nutri Bar for Lactating Women
}

\author{
${ }^{1}$ Kulsum Jan, ${ }^{2}$ Dr Deeba S. Jairajpuri, ${ }^{3}$ Shumaila Jan \\ Department of Food Technology Faculty of Engineering and Interdisciplinary Sciences (FEIS) \\ Jamia Hamdard, Hamdard University, New Delhi-62
}

\begin{abstract}
Nutri bar is a popular food with blend of ingredients to provide nutrition to different age groups most widely recommended for consumption by women (who are pregnant, lactating or are attempting to become pregnant) in an amount that is effective for enhancing their nutrition. Despite the interesting nutritional properties, Nutri bar provides some medicinal properties as well, like demulcent, carminative, laxative, lactogenic, and rubefacient. In present research traditional ingredients, such as fenugreek, dry ginger, gum acacia, have been incorporated into Nutri bar to increase milk production of mothers along with some other ingredients like almonds, cashews, coconut, honey, makhana as nutrition supplement. These ingredients used were assessed at different levels to make a bar of better nutrition. Semolina $(92.5 \mathrm{~g})$ when fortified with makhana $(7.5 \mathrm{~g})$, coconut $(6 \mathrm{~g})$, cashew (5g), almonds $(5 \mathrm{~g})$, fenugreek $(0.1 \mathrm{~g})$, ginger $(0.1 \mathrm{~g})$, gum acacia $(5 \mathrm{~g})$ and honey $(42 \mathrm{~g})$ attained a good consistency, nutritional value and better organoleptic properties. Microbiological studies during storage under ambient temperature conditions were also studied.
\end{abstract}

Keywords: Nutribar, supplementation, sensory quality, semolina, makhana.

\section{Introduction}

A Nutri-bar is a product containing one or more vitamins recommended for consumption by pregnant, lactating women or women of child bearing potential that are attempting to become pregnant, in an amount that is effective for enhancing the nutrition (Paul B. Manning, Jack H. Schramm, 2002).

Ananthan Padmashree, et al. (2010) used wheat flour to produce cereal bars. This bar was supposed to provide 50\% requirement of RDA as per ICMR recommendations. Jane Michnowski (1985) prepared ready-toeat high carbohydrate, low fat, high guar gum snack bar composition for a Type II diabetic comprising 50-75\% carbohydrates, $10-15 \%$ protein, $8-15 \%$ fat and $8-12 \%$ guar gum. A food bar comprising particles of cereal bound together with an edible solid particulate adhesive food composition comprising a particulate protein source in a proportion sufficient that composition contains at least about $15 \%$ by weight protein, between about $33 \%$ and about $85 \%$ by weight of edible fat, fat being substantially solid at room temperature but becoming a smooth fluid at mouth temperature, and up to about $52 \%$ by weight of a carbohydrate selected from the group consisting of monosaccharide and disaccharides, the individual particles of protein source and carbohydrate being substantially coated with fat so as to mask flavors arising from protein.(Ray G. Kelly et al. 1977).

Food bars may also contain wide variety of carbohydrates like monosaccharaides, disaccharides, their hydrolytic products, among proteins; cereal proteins, vegetable proteins, animal proteins, whey proteins, egg proteins. The bars contain food enhancement agents. These agents include a premixed combination of Vitamin A, Vitamin B1, Vitamin B2, Vitamin B6, Vitamin B12, Vitamin C, Vitamin D, Vitamin E, Vitamin K, Biotin, Calcium, Copper, Folic Acid, Iodine, Iron, Magnesium, Manganese, Pantothenic Acid, Phosphorus, and Zinc. Further, calcium may be supplied by a combination of calcium citrate and dicalcium phosphate, the phosphorus is supplied by a combination of dicalcium phosphate and magnesium phosphate, and the magnesium is supplied by magnesium phosphate. (William E bangs, Chor SangHeng, pat no 6,039,978). Nutri bars are also fortified with health promoting agents like DHA.DHA enhances intelligence and helps in IQ development. One or more anti-constipation and regularity-maintaining agents are added in an amount that is effective for reducing or eliminating constipation, and that is not harmful breast-feeding babies, from about 0 to about 99 weight percent of carbohydrates, from about 0 to about 80 weight percent of proteins, and from about 0 to about 60 weight percent of fats (Paul B Manning et al. June 10, 2003).

Leach, Robin L.(1995) worked on an uncooked ready to eat food bar consisting essentially of a mixture of dry ingredients combined with a mixture of liquid ingredients in a ratio of about 3:1 by weight, wherein mixture of dry ingredients includes about $38 \%$ by weight of dry ingredient containing dietary fiber, about $18 \%$ dry ingredient containing non-animal protein, antioxidant, a simple carbohydrate, complex carbohydrate, sugar, lecithin, polyunsaturated linoleic acid, super unsaturated alpha-linoleic acid, amino acid,chlorophyll,pyridoxine,magnesium,sodium, potassium,flavoring, syrup sweetener containing sugar, simple carbohydrate and complex carbohydrate, vegetable oil containing polyunsaturated linoleic acid, wherein the polyunsaturated linoleic acid is present in a ratio of about 3:1 by weight to super unsaturated alpha-linoleic acid. The food bar contains about $35 \%$ by weight of complex carbohydrate, about $17 \%$ by weight of simple 
carbohydrate, potassium is present in the food bar in a ratio of about 10:1 by weight to sodium, and water is present in a ratio of about 1:3 to sugar and is less than about $10 \%$ by weight of the food bar.

Keeping in view, the nutritive and health promoting aspect of plant derivatives; present investigation is aimed to improve the nutritive as well as medicinal valve of nutri bars that can be used as a nutritive food for lactating women, who do not have much time for homemade remedies, moreover can also help in increasing milk production along with some other beneficial health effects.

\section{Materials and Methods}

The raw materials semolina(suji) (A F M Foods), honey (Dabur Honey), dry ginger (MDH dry ginger), gum acacia, makhana (S.S. Foods), almonds (Dhanhar Exim Pvt. Ltd), cashews (Raj Exim Pvt. Ltd), dry dates (Shree Ganesh Trading's), fenugreek (MDH Masale), ghee (Verka ghee), chocolate color (Gulati and Co) were obtained from local market.

Sample PreparationSix samples of the nutribar were prepared using sample one as the control (reference) containing semolina as primary ingredient. From sample 2 to 6 they were fortified with makhana at the rate of $2.5,5,7.5,10$ and $12.5 \%$ respectively, while keeping the other ingredients at constant level.The amount of the

raw materials used for the preparation of Nutri bar samples have been given in the Table1. In sample two the semolinawas replaced by starch. In samples 3-6, sugar was replaced by honey and in sample 3 gelatin was used (from animal origin) in addition to gum acacia.

Nutri bar preparationSemolina/starch and makhana powder blends were prepared in the ratio of 100:0, 97.5:2.5, 95:5, 92.5:7.5, 90:10and 87.5:12.5 respectively. $15 \mathrm{~g}$ of ghee was taken in the flat bottomed pan and heated at $80^{\circ} \mathrm{C}$ and the ingredients (first almonds, then cashew nuts and coconut) were added one by one till they attained brown color.Then fenugreek was fried separately and the excess oil was drained.Prior to frying the ingredients were chopped by knife. The remained ghee was then heated to fry semolina till browningand then gum acacia was added. The stirring was continued until the crystals puff up and the spluttering stops. Thenhoney was added to the roasted flour and stirred the whole until all the ingredients were well blended. And then the dry fruits mixture, chocolate flavor and $0.1 \%$ preservative was added to the roasted flour and mixed well. The mixture was transferred in a large tray and was cut in different shapes of bars and then cooled and packed in LDPE bags for further analysis.

Chemical characteristics Moisture, ash and fat content were determined according to AOAC 2000 methods. Protein content was determined as per (IS: 7219:1973): Kjeldhal Method, protein content was obtained by using the conversion factor of 6.25, Dietary fibre was determined by (IS: 11062) and carbohydrate content by difference method.

Microbial analysis Yeast, mold and Salmonella growth was checked.Analysis at different intervals of time was done at different temperatures for example; for yeasts and molds at $28^{\circ} \mathrm{C}$, for salmonella at $36^{\circ} \mathrm{C}$.

Sensory evaluationNutri bars were evaluated for overall acceptability (colour, texture, aroma and taste) and was carried out as per 9 point Hedonic scale, by the help of ten semi trained judges.

Statistical analysis ANOVA - post hoc comparis-ons. The means were compared using Duncan's multiple range test (2007).

\section{Results And Discussion}

Proximate composition of nutri bar samplesFortification resulted in gradual increase in protein, ash, carbohydrate and dietary fiber content, while as fat content was decreased, as compared to control that is acceptable as per health concern. The results agreed with the other workers who incorporated the plant based raw materials to enhance the nutritional as well as health benefits of nutribar. The results showed a significant difference $(\mathrm{p} \leq 0.05)$ as the fortification was increased, Table 2.

Microbial AnalysisPermitted growth of yeasts, molds and salmonella was found in all the samples at different intervals of time, in processed nutri bar, Table 3.

Sensory CharacteristicsThe Sensory evaluation was carried out as per 9 point Hedonic scale, Table 4. The sensory attributes that were taken into consideration include: color, texture, aroma, taste, overall acceptability and rank. The values are the means of ten readings. Among the five fortified samples, the third sample had highest overall acceptability, compared to the control. 
IV. Tables

Table 1: Amount (in grams) of ingredients used in each sample of nutribar.

\begin{tabular}{ccccccc}
\hline Ingredient & Sample 1 & Sample 2 & Sample 3 & Sample 4 & Sample 5 & Sample 6 \\
\hline Semolina & 100 & - & 95 & 92.5 & 90 & 87.5 \\
Starch & 100 & 97.5 & - & - & - & - \\
Makhana & - & 2.5 & 5 & 7.5 & 10 & 12.5 \\
Sugar & 130 & 130 & - & - & - & - \\
Honey & - & - & 42 & 42 & 42 & 42 \\
Ghee & 50 & 50 & 50 & 50 & 50 & 50 \\
Coconut & 6 & 6 & 6 & 6 & 6 & 6 \\
Cashew nut & 5 & 5 & 5 & 5 & 5 & 5 \\
Almonds & 5 & 5 & 5 & 5 & 5 & 5 \\
Dry ginger & 0.1 & 0.1 & 0.1 & 0.1 & 0.1 & 0.1 \\
Fenugreek & 0.1 & 0.1 & 0.1 & 0.1 & 0.1 & 0.1 \\
Gum acacia & 5 & 5 & 5 & 5 & 5 & 5 \\
Gelatin & - & - & 2 & - & - & - \\
\hline
\end{tabular}

Table 2: Proximate composition ${ }^{\mathrm{a}, \mathrm{b}}$ of nutribar samples.

\begin{tabular}{|c|c|c|c|c|c|c|}
\hline S. No. & Moisture, $\%$ & Ash, \% & Protein, \% & Fat, \% & $\begin{array}{c}\text { Dietary } \\
\text { Fiber, \% }\end{array}$ & $\begin{array}{c}\text { Carbohydra } \\
\text { te } \%\end{array}$ \\
\hline Sample 1 & $8.95 \pm 0.04^{\mathrm{a}}$ & $0.99 \pm 0.06^{\mathrm{a}}$ & $\begin{array}{c}19.93 \pm \\
0.05^{\mathrm{e}}\end{array}$ & $5.03 \pm 0.05^{\mathrm{a}}$ & $1.87 \pm 0.06^{b}$ & $\begin{array}{c}78.87 \pm \\
0.09^{\mathrm{a}}\end{array}$ \\
\hline Sample 2 & $8.93 \pm 0.05^{\mathrm{a}}$ & $1.08 \pm 0.05^{\mathrm{a}}$ & $\begin{array}{l}17.93 \\
\pm 0.05^{\mathrm{b}}\end{array}$ & $5.27 \pm 0.03^{c}$ & $1.80 \pm 0.01^{\mathrm{a}}$ & $\begin{array}{c}81.00 \pm \\
0.08^{\mathrm{b}}\end{array}$ \\
\hline Sample 3 & $9.14 \pm 0.04^{b}$ & $2.13 \pm 0.04^{b}$ & $\begin{array}{c}18.57 \pm \\
0.03^{\mathrm{d}}\end{array}$ & $5.12 \pm 0.02^{\mathrm{b}}$ & $2.50 \pm 0.02^{c}$ & $\begin{array}{c}83.00 \pm \\
0.08^{\mathrm{c}}\end{array}$ \\
\hline Sample 4 & $9.33 \pm 0.02^{c}$ & $2.49 \pm 0.03^{c}$ & $\begin{array}{c}18.29 \pm \\
0.01^{\mathrm{c}}\end{array}$ & $5.45 \pm 0.05^{\mathrm{d}}$ & $2.80 \pm 0.01^{\mathrm{d}}$ & $\begin{array}{c}83.53 \pm \\
0.02^{\mathrm{d}}\end{array}$ \\
\hline Sample 5 & $9.59 \pm 0.05^{\mathrm{d}}$ & $2.59 \pm 0.01^{\mathrm{d}}$ & $\begin{array}{c}18.19 \pm \\
0.06^{\mathrm{c}}\end{array}$ & $5.79 \pm 0.01^{\mathrm{e}}$ & $3.12 \pm 0.02^{\mathrm{e}}$ & $\begin{array}{c}84.56 \pm \\
0.26^{\mathrm{e}}\end{array}$ \\
\hline Sample6 & $9.87 \pm 0.05^{\mathrm{e}}$ & $2.91 \pm 0.01^{\mathrm{e}}$ & $\begin{array}{c}17.72 \pm \\
0.14^{\mathrm{a}}\end{array}$ & $6.11 \pm 0.01^{\mathrm{f}}$ & $3.51 \pm \frac{0.01}{8^{f}}$ & $\begin{array}{c}85.27 \pm \\
0.04^{\mathrm{f}}\end{array}$ \\
\hline
\end{tabular}

${ }^{\mathrm{a}}$ Mean value \pm standard deviation $(\mathrm{n}=3)$

${ }^{b}$ Mean values marked with different superscripts in the same column are significantly different- Duncan ( $\mathrm{p} \leq$ $0.05)$.

Table 3: Microbial analysis of nutribar.

\begin{tabular}{ccccc}
\hline S. No. & Microbial type & After 24 hours & After 15 days & After 30 days \\
\hline 1 & Salmonella & $1.00 \times 1^{-1}$ & $1.00 \times 10^{-1}$ & $1.00 \times 10^{-1}$ \\
2 & Yeast & $0.05 \times 10^{-1}$ & $<1.00 \times 10^{-1}$ & $<1.00 \times 10^{-1}$ \\
3 & Mold & $<1.00 \times 10^{-1}$ & $<1.00 \times 10^{-1}$ & $<1.00 \times 10^{-1}$ \\
\hline
\end{tabular}

Table 4: Sensory characteristics ${ }^{\mathrm{a}, \mathrm{b}}$ of nutribar samples.

\begin{tabular}{cccccc}
\hline S. No. & Color & Texture & Aroma & Taste & Rank \\
\hline Sample 1 & $8.3 \pm 0.60^{\mathrm{e}}$ & $8.00 \pm 0.82^{\mathrm{c}}$ & $8.20 \pm 0.64^{\mathrm{d}}$ & $8.00 \pm 0.8 \mathrm{~b}^{\mathrm{c}}$ & $8.00 \pm 0.82^{\mathrm{c}}$ \\
Sample 2 & $7.40 \pm 0.80^{\mathrm{a}}$ & $7.70 \pm 0.46^{\mathrm{b}}$ & $7.00 \pm 0.89^{\mathrm{a}}$ & $7.70 \pm 0.64^{\mathrm{ab}}$ & $7.30 \pm 0.64^{\mathrm{a}}$ \\
Sample 3 & $8.00 \pm 0.63^{\mathrm{c}}$ & $7.80 \pm 0.60^{\mathrm{bc}}$ & $7.00 \pm 0.89^{\mathrm{a}}$ & $7.90 \pm 0.70^{\mathrm{a}}$ & $7.7 \pm 0.78^{\mathrm{b}}$ \\
Sample 4 & $8.10 \pm 0.54^{\mathrm{d}}$ & $7.8 \pm 0.60^{\mathrm{b}}$ & $8.10 \pm 0.54^{\mathrm{d}}$ & $8.10 \pm 0.30^{\mathrm{c}}$ & $8.00 \pm 0.45 \mathrm{c}$ \\
Sample 5 & $8.00 \pm 0.82^{\mathrm{bc}}$ & $7.90 \pm 0.70^{\mathrm{c}}$ & $7.90 \pm 0.7^{\mathrm{c}}$ & $8.00 \pm 0.63^{\mathrm{b}}$ & $7.9 \pm 0.54^{\mathrm{c}}$ \\
Sample 6 & $7.9 \pm 0.64^{\mathrm{b}}$ & $7.10 \pm 0.54^{\mathrm{a}}$ & $7.40 \pm 0.80^{\mathrm{b}}$ & $7.70 \pm 0.46^{\mathrm{a}}$ & $7.6 \pm 0.89^{\mathrm{b}}$ \\
\hline
\end{tabular}

a Mean value \pm standard deviation $(n=10)$

bMean values marked with different superscripts in the same column are significantly different- Duncan ( $\mathrm{p} \leq$ $0.05)$. 


\section{Figures}

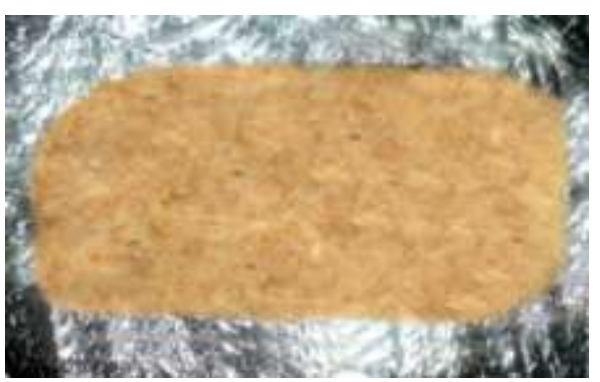

Fig. 1: Fortified sample 1.

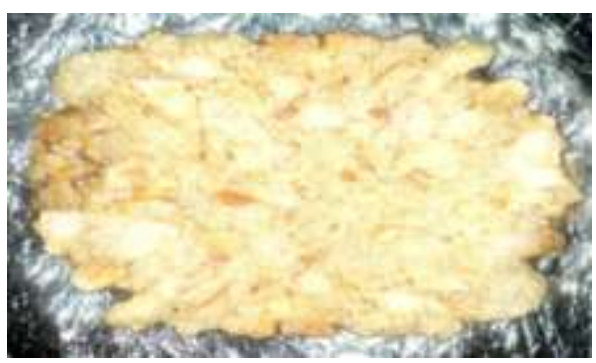

Fig. 2: Fortified sample 2

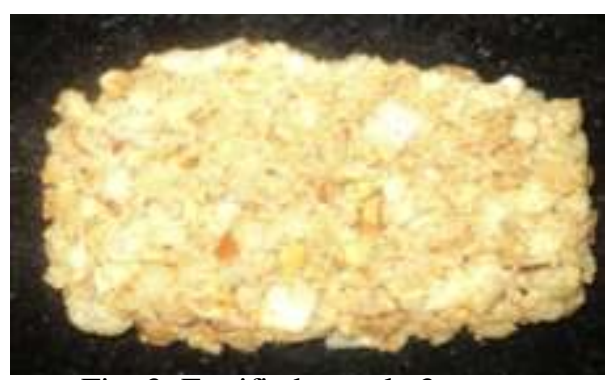

Fig. 3: Fortified sample 3.

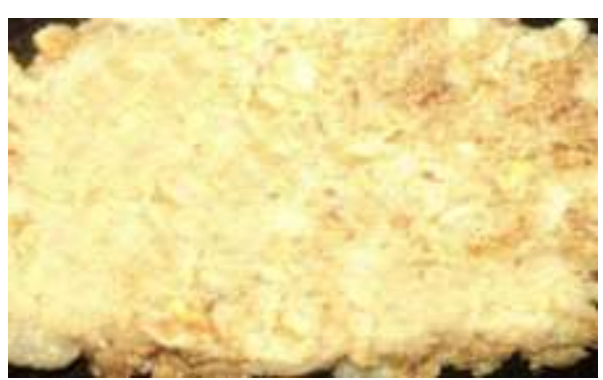

Fig. 4: Fortified sample 4.

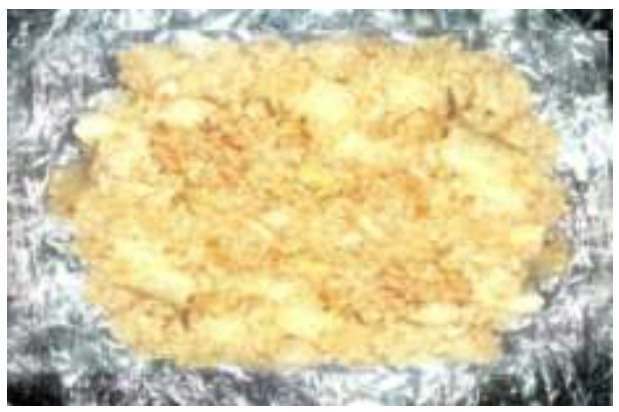

Fig. 5: Fortified sample 5 


\section{Conclusion}

Semolina based nutri bar supplemented with the specific quantity of makhana, fenugreek, gum acacia and dry ginger was successfully produced. Also honey was used to replace sugar as it is more beneficial as far as the digestibility is concerned. Fortification resulted in agradual increase in protein, ash, carbohydrate and dietary fiber content, while as fat content was comparatively decreased. Microbial analysis showed that bar is safe for consumption. Bar when produced from starch produced a poor quality bar in terms of taste, color and consistency. Nutribar when fortified with $7.5 \mathrm{~g}$ makhana resulted in better quality product, sensory and organoleptic analysis was ranked eight points (that is liked very much).

\section{References}

[1] A Hegazy and M I Ibrahium (2009).Evaluation of the nutritional protein quality of wheat based bar supplemented by fenugreek seed flour. World J. of dairy and food sciences 4 (2):129-135.

[2] AACC (1983). Approved Methods of the American Association of Cereal Chemists, St. Paul, Minnesota, USA

[3] Abdel-Aal ESM, Sosulski FW, Youssef MM, Shehata AAY, 1993. Selected nutritional, physical and sensory characteristics of pan and flat breads prepared from composite flours containing fababean. Plant Foods for Human Nutrition, 51: 409-414.

[4] Ananthan Padmashree, Gopal Kumar Sharma, Kadaba Anantharaman Srihari (2010), Amarinder Singh Bawa .Effect of wheat starch in nutri bars;33(6):66-75.

[5] AOAC, 1995. Official Methods of analysis. Washington, DC: Association of analytical chemists.

[6] Jane Michnowski, 1985. Guar Gum Food Bar, USPA Publications.

[7] Leach, Robbin L. 1997, Nutrient Fortified Food Bar, USPA Publications.

[8] Paul B Maning, Jack H Schramm, James W McGrath JR., 2002 Food Bars Containing Nutritional Supplements and Anticonstipation and Regularity Maintaining Agents, USPA Publications, 424-439.

[9] Ray G. Kelly, Kirkwood,Kershman, 1977. Food Bar and Process of Preparing same, USPA Publications.

[10] William E Bangs, Joseph D, Sandy Ko, MacNair, 2001. Prepacked Therapeutic Meal For Treatment of Diet ResponsiveConditions, USPA Publications.

First Author: Kulsum Jan

Authors

M. Tech. Food Technology, FEIS, Deptt of Food Technology, Jamia Hamdard-62

Second Author: Dr. Deeba S. Jairajpuri

Assistant Professor, FEIS, Deptt. Of Food Technology, Jamia Hamdard-62

Third Author: Shumaila Jan

M. Tech. Food Technology, FEIS, Deptt. Of Food Technology, Jamia Hamdard-62 